\title{
BRAND APPEAL AND CUSTOMERS' PATRONAGE OF FAST FOOD FIRMS IN PORT HARCOURT
}

\author{
Harcourt Horsfall (Ph.D.) \\ Senior Lecturer: Department of Marketing \\ Rivers State University, Port Harcourt, Nigeria \\ harcourthorsfall@gmail.com
}

\begin{abstract}
In theory, brand appeal represents an integrated notion employing a broad stretch of routes, methods and tools that may be considered as a strategy for achieving sustainable customer patronage. Although this concept has been thoroughly examined in various studies there is a research gap regarding its usage in generating customer patronage in the fast food industry. The aim of this research project is to examine and evaluate the degree of the application of brand appeal in customer patronage in fast food firms in Rivers State of Nigeria. The population of the study was 65 fast food firms, from which a sample of 39 was drawn based on the Taro Yemen's formula. The simple random sampling technique was employed to select 200 respondents from 39 fast food firms in Rivers State of Nigeria. The data were gathered by questionnaire survey on 200 respondents. 200 copies of questionnaires were received useful, obtaining a 93 percent response rate. The simple regression statistics was used to test the hypotheses. The results illustrates that emotional brand appeal has a strong, positive and significant influence on patronage intention, and a very strong, positive and significant influence on patronage action. The study also found that rational brand appeal has a strong, positive and significant influence on patronage intention and patronage action. The study therefore, concludes that brand appeal significantly influences customer patronage of fast food firms in Rivers State. The study recommends amongst others that fast food managers should focus particularly on emotional brand appeal to ensure that their companies address adequately, patronage intentions and patronage action.
\end{abstract}

Key Words: Brand appeal, Customer patronage, Emotional brand appeal, Rational brand appeal. 


\section{INTRODUCTION}

In recent times, a lot of studies have accumulated to distinguish the interactions between customers and brand (Koll \& Von Wallpach, 2014; Trump, 2014, Hollebeek et al., 2014; Adiele \& Opara, 2014; Ateke et al., 2015; Harcourt \& Ikegwuru, 2018). Customers are sincerely knowledgeable of the effect of brand on their patronage behaviours (Keller 1993, Alba \& Hutchinson, 2000). Malik et al. (2013) assert that brand image plays a consequential role to upgrade any business performance because it is a circular tool which can confidently change customer's purchasing behavior.

Previous studies on the influence of brand on customers' patronage (Swaminathan et al., 2007, Ahluwalia et al. 2000, Ahluwalia et al,. 2001, Cheng et al. 2012, Lisjak et al., 2012) depict that customers with vigorous relationship to brands will demonstrate non- negative reaction to adverse remarks concerning a given brand. This emanates from the fact that customers have peculiar association with brand (Lisjak et al., 2012, Cheng et al., 2012). So, they may not likely do so since it will be tantamount to an expression or intention to inflict injury or damage to oneself (Cheng et al., 2012, Lisjak et al., 2012). Customers response such injury or damage in this path allow them to maintain a complimentary countenance from them to reduce elevated dissension so long as they are personally being challenged (Steele \&Liu 1983). Trump (2014) reasoned that, since injury or damage to brand is injury or damage to the concerned personality, customers might close out this injury or damage through cushioning their brand appraisal or also setting the brand on a position of esteem sufficiently.

According to Porter (1985), firms unfold strategic options anchored on obtainable source of supply or support, potentialities, and other distinguishable faculties to address dynamic customer demands. Kuti and Harrison (2012) as cited in John, Adiele and Nkoro (2013) remark that flourishing and remunerative operations by firms clamor that such strategic design must be fascinating adequately to evoke customer patronage. Besides, analogous with other industries, fast-food firms are occasionally faced with peculiar difficulties in positioning and promoting their products.

A handful of research has been carried out on the fast-food industry internationally (Mattila, 2001) and in Nigeria; this topical area has been investigated from distinct perspectives (Adewuje, Ayinla \& Bakare, 2014; Ateke, Onwujiariri \& Nnennanya, 2015; Salami \& Ajobo, 2012), it was discovered that firms in this industry grapple with grouse competition on how to outwit one another. Thus, this current study attempts to empirically investigate the influence of brand appeal on customer patronage in the fast-food industry in Rivers State of Nigeria.

\section{Statement of the Problem}

Organizations are today facing challenges on how to out-perform one another. As the business topography becomes more and more undulating, firms such as fast-food companies continue to search for the right strategic bearing to navigate. On the other hand, the customer cumbered with his own needs, desires and preferences remains the sole target of these firms. As the customer's taste is ever changing, accessing him through the right strategy becomes every firm's priority. Consequently, in an attempt to gaining sustainable differential advantage over competing firms, brand appeal comes in as a veritable tool of optimal efficiency. 
The activities of fast food firms in a given economy borders on rendering need satisfying services that meet customers' expectations at a profit. They accomplish this by turning in actions and ingenious eatery services that create value for them, and empower the fast food firms to attain their corporate objectives sufficiently. In spite of the numerous plans and programs put in place by fast food firms to satisfy customers, there is still evidence of low patronage. The question that begs for answer is: what could have begot the low customer patronage in the fast food industry in recent times? It seems that customer patronage might not be incoherent with brand appeal. In view of this incertitude and skepticism, this study investigates the nexus between brand appeal and customer patronage in the fast food industry in Rivers State of Nigeria.

\section{LITERATUREREVIEW AND HYPOTHESES}

\section{Brand Appeal}

The word "appeal" has been defined by the World English Dictionary as "the power to attract, please, stimulate, or interest." Appeal borders on what entice customers in, then keeps them coming back and sharing the experience with their networks. This has important implications for generating exponents who likewise generate sales. An appeal can be described as the persuasive selected by the advertiser to make the product attractive to the customer. Wells, Moriarty and Burnett (2006) state that It is the particular way in which a commercial associates with a specific tastes and preferences of customer. It is a linkage between the emotions or logic of the advertisement and the consumer's reaction to the advertisement.

A brand is generally designed to inform and appeal to consumers about a company, onward with its products or services. Brand appeal constitutes one of approximately twenty advertising strategies marketing professionals adopt to convince customers to buy a product, pay for a service, donate to a cause, or in a different way be convinced (Middleton, 2018). A brand appeal alludes to the approach used to attract the attention of consumers in order to influence their feelings toward a brand. Brand appeal attempts to remind people about a brand they are already familiar with, to appeal to their desire to continue with the brand they are familiar with. Brand appeal is said to be effective when a company's target audience is already very aware of the brand that is advertised. Brand appeals are good for audiences who feel a love or affection for a brand and you want to reinforce that love or affection. Brand appeals are also good when a person may be inclined to switch Brand appeals are in form of: Emotional appeals, fear appeals, humuor appeals, rational appeal, sexual appeal and scarcity appeal (Middleton, 2018). This study adopts emotional appeal and rational appeal as dimensions of brand appeal

\section{Emotional Brand Appeal}

Emotional appeals relates to consumers' social and/or psychological needs for purchasing a product or service. Belch and Belch (2012) indicate that emotional appeal will improve the consumers' emotional need and in achieving their psychological status. Wang et al. (2009) and Bulbul et al. (2010) have demonstrated that distinct types of executions on the basis of emotion on various copy platforms like humor, eroticism, fear and love lead to different advertising arose feelings and dissimilarity in the formation of attitude towards the advertisement and brand recognition; and attitude towards the brand and purchase intention. 
Copeland (1924) posits that individual customers buy products and services based on either a rational or emotional reason.

\section{Rational Appeal}

Rational appeals exhibit an inclination to be informative and could assist to determine consumption choice disaccord (Rossiter \& Percy, 1987). Rational appeals concentrates on the consumer's functional, utilitarian or practical need for the product or service. It also stresses attributes of the product or service and the benefit of owning or using a specific brand. Rational appeals outline the facts, logic of persuasion and learning (Belch \& Belch, 2012). Some attributes of rational appeals, such as product/service quality, feature, economy, dependability, efficacy, efficiency, competitive advantage, health, durability, performance, favourable price, convenience and popularity exist (Belch \& Belch, 2012).

\section{Customer Patronage}

In the recent past, customer patronage has been linked with several factors which include physical setting, business location, corporate identity and advanced inclination behaviour (Adiele \& Opara, 2015; Chukwu \& Uzoma, 2014; Nwulu \& Asiegbu, 2015; Ogwo \& Igwe, 2012). Patronage behaviour can therefore be measured by myriads of factors including; patronage intention, shopping enjoyment, satisfaction, time spent, number of items bought, repeat purchase, money spent, share of wallet, patronage action and repeat purchase or repatronage (Nwulu \& Asiegbu, 2015; Paswan et al., 2010). This study is in line with Nwulu and Asiegbu (2015) who adopted patronage intention, patronage action and repeat purchase as the measures of customer patronage.

\section{Patronage Intention}

Fishbein and Ajzen (1975) see consumers purchase intention as an important indicator for predicting consumer behavior. Patronage intention explains the tendency that the consumer will be willing to buy a given product in the future. Zeithaml (1988) observes that merchandize value discernments trigger purchase intentions and purchase behavior in organizations. Hence, purchase intention is found to be influenced by product value. Consumers' aspiration to purchase can also be perceived as an association between their attitude towards a product and its exact purchase. Fishbein and Ajzen (1975) gave three renowned measurement items for estimating purchase intentions: possible to buy, intended to buy and consider buying. Thus, service organizations such as fast food firms can enrich customers purchase behavior by generating value in product offerings to match customers' expectations and assuage their requirements.

\section{Patronage Action}

Significantly, purchase action by a customer subsumes psychological principles that has been evolved to exploit an understanding of consumers needs so that products can developed designed, and communicated in a justified manner that can mirror the applicable and substantial requirements of consumers. Consumer decision making is a process comprised of five stages that people experience when deciding on what products or services to buy. (Grewal \& Levy, 2010) editorialize that conventionally, consumer decision making has been delineated as an analogous of five refined stages known as: need recognition, information search, evaluation of alternatives, purchase decision, and post purchase processes. All decision-making are channeled towards a determination of a purchase action. In view of that, 
Baker et al. (2002) discovered that, consumers' choice impact shoppers' discernments of commodity value and consequently their aspiration to constitute a purchase act.

\section{Empirical Review}

Sharma and Shreya (2017) investigated the impact of emotional advertising in print and electronic media on selected youngsters of Udaipur. The study applied the Questionnaire method and Convenience sampling technique. The Chi square test was employed to test the hypotheses. The study revealed that youngsters of Udaipur can relate with the emotional appeal of the advertisements of the products.

Mai, Nguyen and Truong (2016) examined the effects of television commercials (TVCs) on customers' loyalty through brand awareness in Ho Chi Minh City, Viet Nam, using quantitative approach with structured questionnaires expediently and openly on 300 customers of milk industry. Statistical tools such as factor analysis, multiple regressions, and path analysis were used. This study found that factors of TVCs as well as music, trust, humor, interest, advertising message, repetition, and length were positively associated with brand awareness and customers' loyalty. The results demonstrated that customers' loyalty was significantly and directly affected by trust, interest, brand recall, and brand recognition. Further, customers' loyalty was indirectly affected by the factors of repetition, humor, advertising, message, and trust. It was recommended that advertising managers should advance these factors when they make a decision to advertise their products or services on television to influence customers' brand awareness as well as brand loyalty

Mishra (2009) studied Indian perspective about advertising appeal by means of the survey method, conducted in two stages; in first stage original questionnaire was arranged and applied on 50 judges and later to evaluating the data closing questionnaire was arranged and was applied on 200 respondents in the age group of 18-25 years. Results of the study discovered that persuasiveness, distinctness, perfectness, fascinating, sensational, energetic, aesthetic, elegant and captivating were the factors that materialized for the advertising appeal and dimensions were energetic, sensational, persuasiveness, distinctness and captivating. Factor and dimensions were compared on the basis of gender. It was established that persuasiveness, perfectness, sensational factors and energetic, sensational and persuasiveness dimensions do not differ on the basis of gender as males and females both felt that these factors and dimensions were significant but females perceived that distinctness factor and dimension and aesthetic factor is more significant than males but for males fascinating factor was more important than the females.

As noted earlier, brand appeal has an effect on various aspects of customer patronage. This leads to the following hypotheses:

Ho: Emotional brand appeal does not significantly influence patronage intention.

Ho2: Emotional brand appeal does not significantly influence patronage action.

Ho3: Rational brand appeal does not significantly influence patronage intention.

Ho4: Rational brand appeal does not significantly influence patronage action. 


\section{METHODOLOGY}

The study espouses the quasi-experimental research design (Igweze et al., 2008). The quasi experimental research is a method adopted in social and management sciences. The research setting is a non-contrived one. The study chose a quantitative research approach and a causal design to test the influence of brand appeal on components of customer patronage. This is intended to boost and give confidence to the validity of the study.

The study population was 65 fast food firms registered with the Commercial Department of the Rivers State Ministry of Commerce and Industry, Port Harcourt as at February, 2020. The study accepted the entire firms as study units and employed the Taro Yamane's formula to arrive at the sample size for the study, as depicted in the works of Kelechi (2008) in Ogbadu (2009) was used.

Thus the formulae $n=N / 1+N(c)$ squared

Where $\mathrm{n}$ is the sample size

$\mathrm{N}$ is the population

1 is constant and

e is level of significance (i.e. 0.05).

$$
\text { Therefore; } \begin{aligned}
n & =65 / 1+65(0.05) 2 \\
n & =65 / 1+65(0.0025)=65 / 1+0.6775 \\
n & =65 / 1.677=39 .
\end{aligned}
$$

The sample size of this study was 39 . The simple random sampling technique was used to determine the respondents. A sample of 39 customers of fast food firms was used for the study, where 6 customers of the fast food firms were chosen randomly from each of the 39 fast food firm's premises to make up the total number of 234. The customers of fast food firms were chosen because they can elicit information relating to the patronage of the brand of the firms under study. Thus, 234 questionnaires were distributed to the customers of the firms.

Of the 234 copies of questionnaire that were distributed to the respondents, 215 copies were returned, giving a response rate of 92 percent. The remaining 19(8\%) copies produced and distributed were not returned and were unaccounted for. Additionally, of the 215 copies of the questionnaire returned, the usable copies numbered 200 leading to a response rate of 93 $\%$. However, $7 \%$ (15 copies) was not used due to wrong filling, missing and incomplete information in the demographic profile. Hence, these 200 copies were employed for the investigation. The study used the simple regression analysis to test the four hypotheses of concern with the aid of computer by means of the statistical package for social science (SPSS) version 22.0 package. 


\section{ANALYSIS}

\section{Test of Hypotheses}

In this section, results of the study are presented. The null hypothesis being verified states that dependent variables are not significantly influenced by the independent variable (brand appeal). This hypothesis is tested at $5 \%$ significance level. The objective of this analysis is to see if brand appeal influence customer patronage in fast food firms in Rivers State. The study confirmed the reliability of data before presenting the results of the test of hypotheses.

\section{Decision Rule}

Significant/probability value $(\mathrm{Pv})<0.05$ (level of significance $=$ conclude significant influence.

Significant probability value $(\mathrm{Pv})>0.05$ (level of significant $=$ conclude insignificant influence.

\section{Influence of Brand Appeal on Patronage Intentions}

Table 1: Influence of Emotional brand appeal on patronage intentions $(n=200)$.

\begin{tabular}{crccc}
\hline Model RR Square & Adjusted R Square Std. Error of the estimate & Sig \\
1 & .810 .656 & .653 & .50668 & 0.000
\end{tabular}

a. Predictors: (Constant), Emotional Brand Appeal

b. Dependent Variable: Patronage Intentions

The Coefficient of correlation $(\mathrm{R})$ can be considered as a measure of the quality of the prediction of the independent variable. The value of 0.810 indicates a good level prediction. The Coefficient of determination ( $\mathrm{R}$-square) is the proportion of variation in the dependent variable (patronage intentions) that is explained by the independent variables. Hence, 65.6 percent of the patronage intentions can be explained by independent variables in the model. The adjusted R-square is used to test the overestimation of $\mathrm{R}$ square. The estimates show an error of .50668, which cannot be considered as very large. The emotional brand appeal variable exact significant influence on patronage intentions in fast food firms in Rivers State, since the sig. (or p-value) is .000 which is below the 0.05 level of significance.

\section{Influence of Emotional brand Appeal on Patronage Actions}

Table 2: Influence of Emotional brand appeal on patronage actions $(n=200)$.

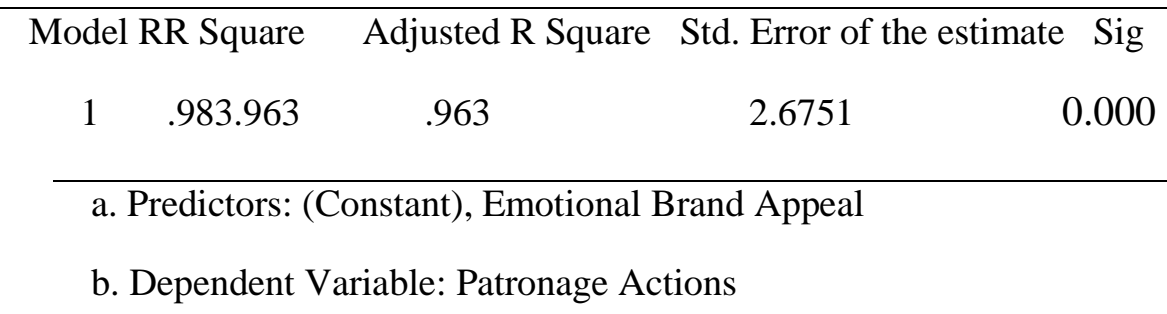


The Coefficient of correlation (R) can be considered as a measure of the quality of the prediction of the independent variable. The value of 0.983 indicates a good level prediction. The Coefficient of determination (R-square) is the proportion of variation in the dependent variable (patronage actions) that is explained by the independent variables. Hence, 96.3 percent of the patronage actions can be explained by independent variables in the model. The adjusted R-square is used to test the overestimation of $\mathrm{R}$ square. The estimates show an error of 2.6751 which cannot be considered as very large. The emotional brand appeal variable exact significant influence on patronage actions in fast food firms in Rivers State, since the sig. (or p-value) is .000 which is below the 0.05 level of significance.

\section{Influence of Rational Brand Appeal on Patronage Intention}

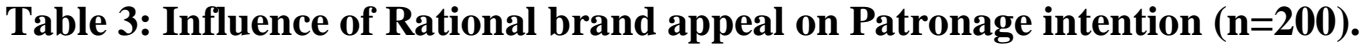

\begin{tabular}{cccc}
\hline Model & RR Square & Adjusted R Square & Std. Error of the estimate \\
1 & .776 .603 & .553 & .08878
\end{tabular}

a. Predictors: (Constant), Rational Brand Appeal

b. Dependent Variable: Patronage Intention

The Coefficient of correlation $(\mathrm{R})$ can be considered as a measure of the quality of the prediction of the independent variable. The value of 0.776 indicates a good level prediction. The Coefficient of determination (R-square) is the proportion of variation in the dependent variable (patronage intention) that is explained by the independent variables. Hence, 60.3 percent of the patronage intentions can be explained by independent variables in the model. The adjusted R-square is used to test the overestimation of $\mathrm{R}$ square. The estimates show an error of.08878 which cannot be considered as very large. The rational brand appeal variable exact significant influence on patronage intention fast food firms in Rivers State, since the sig. (or p-value) is .000 which is below the 0.05 level of significance.

\section{Influence of Rational brand appeal on Patronage Actions}

Table 4: Influence of Rational brand appeal on patronage actions $(n=200)$.

\begin{tabular}{ccccc}
\hline Model & RR Square & Adjusted R Square & Std. Error of the estimate & Sig \\
1 & .712 .506 & .5071 & .421 & 0.000
\end{tabular}

\footnotetext{
a. Predictors: (Constant), Rational Brand Appeal

b. Dependent Variable: Patronage Actions
}

The Coefficient of correlation $(\mathrm{R})$ can be considered as a measure of the quality of the prediction of the independent variable. The value of 0.712 indicates a good level prediction. The Coefficient of determination ( $\mathrm{R}$-square) is the proportion of variation in the dependent variable (patronage actions) that is explained by the independent variables. Hence, 71.2 
percent of the patronage actions can be explained by independent variables in the model. The adjusted R-square is used to test the overestimation of $\mathrm{R}$ square. The estimates show an error of 1.421 which cannot be considered as very large. The rational brand appeal variable exact significant influence on patronage actions in fast food firms in Rivers State, since the sig. (or p-value) is .000 which is below the 0.05 level of significance.

\section{DISCUSSIONS OF FINDINGS}

In this research, the effect of brand appeal on customer patronage was investigated. The measures studied in this research are patronage intentions and patronage actions. In this study, we realized a significance positive influence of brand appeal on the components of customer patronage (patronage intention and patronage actions). The results show that emotional brand appeal is more influential on patronage actions (.983) and then on patronage intentions (810). This implies that customer patronage ameliorates as the effectiveness of activities of brand appeal is enhanced among the fast food firms. Besides, brand appeal significantly predicts customer patronage. Hence, there is material substantiation that the customer patronage of fast food firms in Rivers State of Nigeria is largely influenced by brand appeal. This finding is in conformity with that of Dunn and Haag (2014) who examined the impact of fear on emotional brand attachment and found a significant interaction between consumption and emotion.

Further, our finding shows a significant effect of brand appeal components on customer patronage. When emotional brand appeal and rational brand appeal are combined and regressed with customer patronage, a strong and significant effect was revealed. Our finding shows that the combined brand appeal components influence customer patronage. This implies that when firms noticed that the business terrain is becoming tough for them to operate; they introduce well articulated combined brand appeal programmes to endear customer patronage. The relationship is statistically significant. Emotional brand appeal and rational brand appeal can be powerful marketing strategies that facilitate competitiveness that will revolutionalize customer patronage positively. The results of our study support OonFokYew et al. (2013) assertion that companies need a high level of integration of their strategies, actions, programs, practice, and performance to remain competitive.

Brand appeal and customer patronage are strategically important to business organizations and to performance in industries and the study provides evidence of the ways in which business organizations strike various balances in brand appeal to attain customer patronage. In the broadest sense, this study makes it clear why it is useful to take a broad view when handling brand appeal phenomenon. More specifically, the dimensions of brand appeal may offer descriptive and prescriptive strategic "shorthand" for firms developing appropriate strategies to influence customer patronage and understand the implicit and explicit tradeoffs involved in branding strategies decisions and practices. This study offers sensitive contributions to the branding literature, with its examination of business-enabled transformation using brand appeal phenomenon. First, the study demonstrates how fast food firms responded to poor customer patronage by employing brand appeal strategies. It highlights how the utilization of these strategies can help fast food firms overcome negative tendencies associated with customer patronage and transform their companies. Second, the study reveals how a critical examination of brand appeal by managers of fast food firms helps to sensitize, seize, and reconfigure their resources to improve customer patronage. 


\section{CONCLUSION}

This work focused on investigating the influence of brand appeal on customer patronage in fast food firms in Port Harcourt. It is evident from the findings that there is implicit relationship between brand appeal and customer patronage. Based on the empirical tests carried out and the discussion of findings, this paper asserts that brand appeal is an antecedent for improved customer patronage, and concludes that brand appeal significantly influences customer patronage in fast food firms in Rivers State of Nigeria.

\section{Recommendations}

Based on the findings of the study, the following recommendations were proffered:

1. Fast food firms' managers should focus predominantly on emotional brand appeal to ensure that their companies address adequately patronage intentions and patronage actions to enhance customer patronage.

2. Managers of fast food firms should position strategically, the components of brand appeal identified by this study to customer patronage. In view of the fact that the study unveiled a statistically significant relationship between them, they should consider brand appeal as a powerful strategy for achieving customer patronage in their organizations.

3. Besides, the study recommends that management of fast food firms should adopt the operational framework of this study which has been developed and translated into practical guidance for managers. This operational framework provides specific boosters for creating the success of brand appeal in predicting positively, customer patronage.

4. Finally, in order to enhance brand appeal in firms, managers should design brand appeal boosting programs that are capable of enhancing positive customer patronage. 


\section{References}

Adiele, K. C., \& Opara, B. C. (2014). Analysis of corporate identity on customer patronage of banks in Nigeria. International Review of Management and Business Research, 3(4), 1809.

Ahluwalia, R., Unnava, H. R. \&Burnkrant, R. E. (2001). The moderating role of commitment on the spillover effect of marketing communications. Journal of Marketing Research, $38(4), 458-470$.

Asiegbu, F. I., Awa, H. O., Akpotu, C., \& Ogbonna, U. B. (2011). Sales force competence development and marketing performance of industrial and domestic products firms in Nigeria. Far East Journal of Psychology and Business, 2 (3), 43-59.

Ateke, B. W., Onwujiariri, J. C., \& Nnennanya, D. A. (2015). The relationship between celebrity endorsement and brand image in the fast food industry in Port Harcourt, Nigeria. European Journal of Business and Management, 7(27), 177-186.

Baker, J., Parasuraman, A., Grewal, D. \& Voss, G. (2002). The influence of multiple store environment cues on perceived merchandise value and patronage intentions. Journal of Marketing, 66, 120-141.

Belch, G.E. \& Belch, M.A. (2012). Advertising and promotion: An integrated marketing communication perspective, 9th Ed, McGraw-Hill. Singapore, 290-294.

Caudill, E. M., \& Murphy, P. E. (2000). Consumer online privacy: Legal and ethical issues. Journal of Public Policy and Marketing, 19, 7-19.

Cheng, S. Y., White, T. B. \& Chaplin, L. N. (2012). The effects of self-brand connections on responses to brand failure: A new look at the consumer-brand relationship. Journal of Consumer Psychology, 22(2), 280-288

Chukwu, B., \& Uzoma, I. (2014). Impact of social media networks on consume patronage in Nigeria: A study of Jumia and Konga Nigeria limited. European Journal of Business and Management, 6(30), 63-70.

Copeland, M. T. (1924), Principles of Merchandising, Aano Press, NY.

Dipeolu, A., Adewuyi, S., Ayinla, M., \& Bakare, A. (2014).Customer satisfaction in fast food restaurants in Ibadan metropolis. Journal of Marketing and Consumer Research, 5, 12-19.

Harcourt, H. \&Ikegwuru, M. (2018). Analyzing the impact of brand loyalty on market performance: A study of food and beverage firms in Rivers State. Journal of Business and African Economy. 4 (1), 25 -38.

Hollebeek, L. D., Glynn, M. S. \& Brodie, R. J. (2014). Consumer brand engagement in social media: Conceptualization, scale development and validation, Journal of Interactive Marketing, 28(2), 149- 165. 
John, A. G., Adiele, K., \& Nkoro, F. (2013).Physical settings and patronage of three star hotels in Nigeria's federal capital territory Abuja. International Journal of Business Management \& Economic Research.4(3), 738-744.

Keller, K.L. (2003). Strategic brand management: Building, measuring, and managing brand equity, (2nd ed.,). Prentice-Hall, Upper Saddle River, NJ

Koll, O. \& von Wallpach, S. (2014). Intended brand associations: Do they really drive consumer response?.Journal of Business Research, 67(7), 1501-1507

Lisjak, M., Lee, A. Y. \& Gardner, W. L. (2012). When a threat to the brand is a threat to the self: The importance of brand identification and implicit self-esteem in predicting defensiveness, Personality and Social Psychology Bulletin, 38(9), 1120-1132

Mattila, A. S. (2001). Emotional bonding and restaurant loyalty. Cornell Hospitality Quarterly, 42(6), 73.

Mai, N. K,, Nguyen V. A. \&Truong, D. N. (2016). The effect of television commercials on customers' loyalty - A mediation analysis of brand awareness. International Journal of Trade, Economics and Finance, 7(2), 18-24.

Middleton, D. (2018). 23Advertising appeals to engage and motivate. Retrieved from www.google.com. Accessed on February 24,2019.

Mishra, M. (2009). Indian perspective about advertising appeal. International Journal of Marketing Studies, 1(2),23-34

Nwulu, C. S., \&Asiegbu, I. F. (2015).Advancement inclination behaviors and university academic staff patronage of deposit money banks in Port Harcourt. International Journal Business and Management, 7(27), 177-186

Ogwo, O. E., \&Igwe, S. R. (2012). Some key factors influencing attitudes to patronage of GSM services: The Nigerian experience. International Journal of Business and Management, 7(18), 82.

Otley, P. (2016, March 23). Can you feel it? Why brands must focus on emotional connection. Digital Pulse. http://www.digitalpulse.pwc.com/au/branded-contentemotional-connection/

Rajagopal, R. (2006).Brand excellence: measuring the impact of advertising and brand personality on buying decisions. Measuring Business Excellence, 10(3), 56-65.

Rossiter, J., \& Bellman, S. (2012). Emotional branding pays off: How brands meet share of requirements through bonding, companionship, and love. Journal of Advertising Research,52(3), 291-296.

Rossiter, J.R. \& Percy, L (1987). Advertising and Promotional Management, McGraw-Hill, New York.

Salami, C., \&Ajobo, R. (2012).Consumer perceptions about fast food restaurants in Asaba. Global Journal of Management and Business Research, 12(1), 75-81. 
Sharma, S. \& Shreya J. (2017).An empirical study on impact of emotional advertising in print and electronic media on selected youngsters of Udaipur. Imperial Journal of Interdisciplinary Research (IJIR), 3(3), 406-412.

Sheth, J.N. (1971). Word of mouth in low-risk innovation. Journal of Advertising Research.11 (3), 15-18.

Sheppard, B. H., Hartwick, J.\&Warshaw, P. R. (1988). The theory of reasoned action: A meta-analysis of past research with recommendations for modifications and future research. Journal of Consumer Research, 15(3), 325-343

Steele, C. M. \& Liu, T. J. (1983). Dissonance processes as self-affirmation, Journal of personality and Social Psychology, 45(1), 5.

Trump, R. K. (2014). Connected consumers' responses to negative brand actions: The roles of transgression selfrelevance and domain, Journal of Business Research, 67(9), 18241830 .

Wang K, Wang Eric T. G. \& Cheng, K. F. (2009), Influence of Web advertising strategies, consumer goal directedness and consumer involvement on Web advertising effectiveness. International Journal of E Commerce, 13 (4), 67-95

Wells W., Moriarty S. \& Burnett J. (2006). Advertising principles and practices 7 thedn. Pearson Prentice Hall, Upper Saddle River: 2006.

Wirtz, J \&Lwin, M.O (2009). Regulatory focus theory, trust, and privacy concern. Journal of Science Research, 12(2), 190-207. 